\title{
SALIVARY GLUCOSE CONCENTRATION IN TYPE-II DIABETIC PEOPLE: A CASE-CONTROL STUDY
}

\author{
NIRMALA A ${ }^{1 *}$, MAZHER SULTANA ${ }^{2}$, SHARON NS ${ }^{3}$ \\ ${ }^{1}$ Department of Biotechnology, Aarupadai Veedu Institute of Technology, Vinayaka Missions Research Foundation, Kanchipuram, \\ Tamil Nadu, India. ${ }^{2}$ Department of Zoology, Presidency College, Chennai, Tamil Nadu, India. ${ }^{3}$ Department of Biochemistry, Meenakshi \\ Ammal Dental College, MAHER (Deemed to be University), Chennai, Tamil Nadu, India. Email: drnirmala81@gmail.com
}

Received: 01 July 2019, Revised and Accepted: 26 October 2019

ABSTRACT

Objective: The objective of the present study was to find a non-invasive method of sample collection that can be used to diagnose and monitor diabetes mellitus (DM).

Methods: In this study, saliva as a diagnostic fluid was collected noninvasively from subjects with modest training and this offers a cost-effective method for screening diabetes. To evaluate the association of blood glucose level with salivary glucose in Type-II diabetic mellitus (Type-II DM) pattients, a case-control study was conducted on 200 test and 200 healthy control people in selected study village in Kanchipuram (District). The glucose level was measured in saliva and blood plasma by glucose oxidase and peroxidase method.

Results: A highly significant positive correlation between fasting salivary glucose (69.377 $\pm 14.329 \mathrm{mg} / \mathrm{dl})$ and plasma glucose (249.935 $\pm 64.65 \mathrm{mg} / \mathrm{dl})$ in diabetic patients and in control group, plasma glucose level $117.545 \pm 10.595$ and saliva glucose level $49.271 \pm 13.795 \mathrm{mg} / \mathrm{dl}$ was observed.

Conclusion: From this study, it can be concluded that fasting salivary glucose level can be used as a non-invasive diagnostic, as well as monitoring tool to assess the glycemic status of Type-II DM patients.

Keywords: Blood glucose level, Salivary glucose level, Diabetes mellitus, Saliva, Hyperglycemia.

(C) 2019 The Authors. Published by Innovare Academic Sciences Pvt Ltd. This is an open access article under the CC BY license (http://creativecommons. org/licenses/by/4. 0/) DOI: http://dx.doi.org/10.22159/ajpcr.2019.v12i11.34739

\section{INTRODUCTION}

Diabetes mellitus (DM) is a heterogeneous (clinically and genetically) metabolic disease characterized by hyperglycemia and dysregulation of carbohydrate, protein, and lipid metabolism [1]. The main feature of DM is chronic hyperglycemia, resulting from either a defect in insulin secretion from pancreas or resistance of body's cells to produce insulin or both. The characteristic symptoms of diabetes are polyuria, polydipsia, polyphagia, and unexpected weight loss [2]. DM in India is gaining the status of a potential epidemic disease with more than 62 million people diagnosed with DM [3,4]. In the year 2000, India topped the world with the highest number of people having DM (31.7 million) followed by China (20.8 million) in the second place and the United States (17.7 million) in the third place [5-8].

Blood has been the most commonly used diagnostic fluid for the analysis of its various constituents. This study is focused on the fact that saliva being the principle and defensive fluid in the mouth with informative components can serve as diagnostic tool for human diseases. Collection of saliva is cost effective and non-invasive when compared to blood. The present study is proposed to measure the correlation between salivary and blood glucose levels in diabetic and non-diabetic subjects.

\section{METHODS}

\section{Sample collection, processing, and storage}

Diabetes camp was conducted to collect the sample from 200 control group and 200 Type-II diabetic people with different age groups from the selected study area of Thiruporur, Kanchipuram (District). The study was approved by the members of the Institutional Ethical Committee. Exclusion criteria for the control group were pregnancy, alcohol dependency, smoking, chronic diseases, and history of diabetes. After explaining and obtaining an informed consent, all subjects were advised to come on overnight fasting (12 h) before collection of unstimulated whole saliva samples. Denture wearers removed their dentures before saliva collection. Before collection, the subjects rinsed their mouth with water. After $5 \mathrm{~min}$, the saliva was collected in the graduated collection test tube [9-14]. Flow rate was measured by recording the reading in the tube. The saliva samples were centrifuged at $4000 \mathrm{rpm}$ for $15 \mathrm{~min}$ to remove any particulate material and then supernatant was transferred to a sterile vial immediately, stored at $-20^{\circ} \mathrm{C}$ for further investigations.

\section{Estimation of salivary glucose}

\section{Principle}

Glucose is oxidized to gluconic acid and hydrogen peroxide in the presence of glucose oxidase. Hydrogen peroxide further reacts with phenol and 4-aminoantipyrine by the catalytic action of peroxidase to form a red-colored quinoneimine dye complex. Intensity of the color formed is directly proportional to the amount of glucose present in the sample.

$$
\alpha-D-\text { Glucose } \stackrel{\text { Mutarotase }}{\rightarrow} \beta-D \text { Glucose }
$$

$$
\begin{gathered}
\beta-\mathrm{D} \text { - Glucose }+\mathrm{H}_{2} \mathrm{O}_{2} \stackrel{\text { Glucose Oxidase }}{\rightarrow} \text { D-Gluconic acid }+\mathrm{H}_{2} \mathrm{O}_{2} \\
\mathrm{H}_{2} \mathrm{O}_{2}+4 \text { Aminophenazone }+ \text { Phenol } \stackrel{\text { Peroxidase }}{\rightarrow} \text { Quinoeimine }+4 \mathrm{H}_{2} \mathrm{O}_{2}
\end{gathered}
$$

Reagent

Ready to use reagents provided by the kit.

Sample

The sample was plasma and saliva. 
Procedure

Wavelength/filter: $505 \mathrm{~nm}$

Temperature: $37^{\circ} \mathrm{C} / \mathrm{RT}$

Light path: $1 \mathrm{~cm}$

Pipette into clean dry test tubes labeled as blank (B), standard (S), and test (T).

\begin{tabular}{llll}
\hline Additional sequence & B (ml) & $\mathbf{S}(\mathbf{m l})$ & T (ml) \\
\hline Distilled water & 0.01 & - & - \\
Glucose standard (S) & - & 0.01 & \\
Sample-plasma & - & - & - \\
Fasting/postprandial/saliva & & & 0.01 \\
Glucose reagent (GOD-POD) & 1.0 & 1.0 & 1.0 \\
\hline
\end{tabular}

GOD-POD: Glucose oxidase-peroxidase

Mix well and incubate at $37^{\circ} \mathrm{C}$ for $10 \mathrm{~min}$. Measure the absorbance of the standard (Abs. S) and test (Abs. T) against the blank, within $60 \mathrm{~min}$ at $505 \mathrm{~nm}$ and record the readings.

Calculation

$$
\text { Total glucose concentration in } \mathrm{mg} / \mathrm{dl}=\frac{\text { Abs.T }}{\text { Abs.S }} \times 100
$$

\section{Statistical analysis}

Statistical analysis was performed using GraphPad software. Descriptive statistics on each study variable including mean and standard deviations were analyzed. The results obtained from the analysis were tabulated expressed using mean \pm SD with their level of significance at $p<0.0001$.

\section{RESULTS}

The results were tabulated (Tables 1 and 2).

The observed results were given as mean \pm SD with their level of significant at p-value.

The fasting and postprandial mean plasma glucose concentration in the test group $(155.48 \pm 45.577$ and $249.935 \pm 64.65 \mathrm{mg} / \mathrm{dl})$ were higher than the control subjects. The mean of fasting plasma glucose concentration was $92.495 \pm 8.053 \mathrm{mg} / \mathrm{dl}$ and postprandial plasma glucose concentration was $117.545 \pm 10.595 \mathrm{mg} / \mathrm{dl}$ in the control group (Table 1). Significantly elevated plasma glucose concentration was observed in diabetic patient than the control people at $\mathrm{p}<0.0001$.

Salivary fasting glucose concentration of the test group $(69.377 \pm 14.329 \mathrm{mg} / \mathrm{dl})$ was significantly higher as compared with control subjects $(49.271 \pm 13.795 \mathrm{mg} / \mathrm{dl}$ ) (Table 2$)$.

\section{DISCUSSION}

Monitoring the blood glucose by the physician is important for monitoring diabetic control. The routine diagnostic sample is usually blood being invasive, painful, causing discomfort, and may also limit frequent testing of blood sugar level in diabetic patients. The increased blood glucose readily diffuses through the semipermeable membrane and can be detected in saliva also. Salivary glucose assessment may provide a cost-effective approach as saliva is convenient diagnostic fluid for screening large population. In the present study, glucose concentration in blood and saliva of selected study population (control and diabetic people) was analyzed and compared.

Fasting blood sugar and postprandial blood sugar and fasting salivary glucose concentration were measured in control and diabetic people. The fasting and postprandial blood mean sugar level in diabetic patients are significantly higher $(\mathrm{p}<0.0001)$ than control subjects. A significantly elevated salivary glucose was observed in diabetic patients than the control subjects. The present study result was found to be similar with other scientific reports [15-22]. Kortuem was the first person to study correlation between blood glucose level and salivary glucose
Table 1: Comparison of controls and diabetics with blood glucose levels

\begin{tabular}{llll}
\hline Parameter & \multicolumn{1}{l}{ Blood } & p-value \\
\cline { 2 - 3 } & Control (n-200) & Test (n-200) & \\
\hline $\begin{array}{l}\text { Fasting blood } \\
\text { glucose }\end{array}$ & $92.495 \pm 8.053$ & $155.48 \pm 45.577$ & $0.0001^{* * *}$ \\
$\begin{array}{l}\text { (mg/dl plasma) } \\
\text { PP glucose }\end{array}$ & $117.545 \pm 10.595$ & $249.935 \pm 64.65$ & $0.0001^{* * *}$ \\
$(\mathrm{mg} / \mathrm{dl})$ & & & \\
\hline $\begin{array}{l}\text { n-Number of subject (control-200, test-200). Fasting blood levels were } \\
\text { compared between control and test group, the values were statistically } \\
\text { significant at p=0.000***, PP: Postprandial }\end{array}$ & &
\end{tabular}

Table 2: Comparison of Controls and Diabetics with salivary glucose levels

\begin{tabular}{llll}
\hline Parameter & \multicolumn{2}{l}{ Saliva } & p-value \\
\cline { 2 - 3 } & Control (n-200) & Test $(\mathbf{n}-\mathbf{2 0 0 )}$ & \\
\hline $\begin{array}{l}\text { Fasting glucose } \\
(\mathrm{mg} / \mathrm{dl})\end{array}$ & $49.271 \pm 13.795$ & $69.377 \pm 14.329$ & $0.0001^{* * *}$ \\
\hline $\begin{array}{l}\mathrm{n}-\mathrm{Number} \text { of subject (control-200, test-200). Fasting salivary glucose levels } \\
\text { were compared between the control and test group, the values were statistically } \\
\text { significant at } \mathrm{p}=0.000^{* * *}\end{array}$ & &
\end{tabular}

level in 1944 [23] followed by Shannon et al. [24]. Later on, Englander et al. [25] and Campbell, in 1965, shed light on it [26]. Carlson and Ryan (1908) reported the presence of sugar in saliva of diabetic patients [27] and other authors have also reported the increase in salivary glucose levels in diabetics over the non-diabetics [15-22].

Darwazeh et al. in their study correlated the salivary glucose concentrations with the plasma glucose concentration and indicated the presence of glucose in saliva of diabetics reflects the high plasma glucose concentrations [11]. However, Reuterving et al. (1987) reported that the salivary glucose concentration was low during better metabolic control period [15].

Similar to our study, Mahdavi et al. [28] have reported the presence of sugar in significant amount in saliva of diabetic patients and many other authors including Panchbhai et al. [29], Priya et al. [30], Amer et al. [19], Agrawal et al. [31], Abikshyeet et al. [32], and Ivanovski et al. [33] have also reported the increase in salivary glucose concentration in DM patients when compared to non-diabetics. However, contradictory to our study, Bakianian Vaziri et al. [34] concluded that there was no statistically significant difference in salivary glucose concentration between diabetic patients and control subjects. Vasconcelos et al. (2010) also reported a significantly higher salivary glucose level in diabetics when compared to nondiabetics irrespective of periodontal disease [35]. In this study, salivary glucose concentration is higher in diabetics when compared to that of healthy controls.

\section{CONCLUSION}

A significant positive correlation was established between blood glucose and salivary glucose levels. Hence, it can be concluded that fasting salivary glucose level can be used as a non-invasive diagnostic tool to monitor diabetes. It is possible that tests based on saliva can have a substantial role in diagnosis and also early detection of DM.

\section{ACKNOWLEDGMENT}

The authors are thankful to Aarupadai Veedu Institute of Technology, Vinayaka Missions Research Foundation and Meenakshi Ammal Dental College for providing laboratory facility and their support. 


\section{AUTHORS' CONTRIBUTIONS}

The first author has done the work and compiled the information. The second and third authors have reviewed the manuscript.

\section{CONFLICTS OF INTEREST}

The authors declare that there are no conflicts of interest regarding the publication of this paper.

\section{REFERENCES}

1. Rath D, Panigrahy SR, Panigrahi SK, Kar DB, Maharana L. Antidiabetic effect of extracts of blumealaceradc in streptozotocin induced hyperglycemic rats. Inter J Pharm Pharm Sci 2017;9:218-23.

2. Bhargavi G, Josthna P, Naidu CV. Antidiabetic effect and phytochemical screening of ethanolic extract of Polyalthia cerasoides stem bark in streptozotocin induced diabetic albino rats. Inter J Pharm Pharm Sci 2015;7:154-8

3. Joshi SR, Parikh RM. India--diabetes capital of the world: Now heading towards hypertension. J Assoc Physicians India 2007;55:323-4.

4. Kumar BP, Dudala SR, Rao AR. Kuppuswamy's socio-economic status scale a revision of economic parameter for 2012. Inter J Res Dev Health 2013;1:2-4.

5. Wild S, Roglic G, Green A, Sicree R, King H. Global prevalence of diabetes: Estimates for the year 2000 and projections for 2030. Diabetes Care 2004;27:1047-53

6. Whiting DR, Guariguata L, Weil C, Shaw J. IDF diabetes atlas: Global estimates of the prevalence of diabetes for 2011 and 2030. Diabetes Res Clin Pract 2011;94:311-21.

7. Diabetes Facts. In: IDF Diabetes Atlas. $6^{\text {th }}$ ed. 2013. Available from: http://www.idf.org/diabetesatlas. [Last accessed on 2014 Dec 12].

8. Little RR, Goldstein DE. Endocrine (standardization of glycohemoglobin measurement). Anal Chem 1995;67:393R-7.

9. Sharon A, Ben-Aryeh H, Itzhak B, Yoram K, Szargel R, Gutman D, et al. Salivary composition in diabetic patients. J Oral Med 1985;40:23-6.

10. Thorstensson H, Falk H, Hugoson A, Olsson J. Some salivary factors in insulin-dependent diabetics. Acta Odontol Scand 1989;47:175-83.

11. Darwazeh AM, MacFarlane TW, McCuish A, Lamey PJ. Mixed salivary glucose levels and candidal carriage in patients with diabetes mellitus. J Oral Pathol Med 1991;20:280-3.

12. Chávez EM, Borrell LN, Taylor GW, Ship JA. A longitudinal analysis of salivary flow in control subjects and older adults with type 2 diabetes. Oral Surg Oral Med Oral Pathol Oral Radiol Endod 2001;91:166-73.

13. Pal P, Desai NT, Kannan N, Masur VN, Daniel MJ, Bhatt N. Estimation of salivary amylase, salivary total protein and periodontal microflora in diabetes mellitus. J Indian Dent Assoc 2003;74:143-9.

14. Aydin S. A comparison of ghrelin, glucose, alpha-amylase and protein levels in saliva from diabetics. J Biochem Mol Biol 2007;40:29-35.

15. Reuterving CO, Reuterving G, Hägg E, Ericson T. Salivary flow rate and salivary glucose concentration in patients with diabetes mellitus influence of severity of diabetes. Diabete Metab 1987;13:457-62.

16. Ben-Aryeh H, Cohen M, Kanter Y, Szargel R, Laufer D. Salivary composition in diabetic patients. J Diabet Complications 1988;2:96-9.
17. Belazi MA, Galli-Tsinopoulou A, Drakoulakos D, Fleva A, Papanayiotou PH. Salivary alterations in insulin-dependent diabetes mellitus. Int J Paediatr Dent 1998;8:29-33.

18. Borg Andersson A, Birkhed D, Berntorp K, Lindgärde F, Matsson L. Glucose concentration in parotid saliva after glucose/food intake in individuals with glucose intolerance and diabetes mellitus. Eur J Oral Sci 1998;106:931-7.

19. Amer S, Yousuf M, Siddqiui PQ, Alam J. Salivary glucose concentrations in patients with diabetes mellitus--a minimally invasive technique for monitoring blood glucose levels. Pak J Pharm Sci 2001;14:33-7.

20. López ME, Colloca ME, Páez RG, Schallmach JN, Koss MA, Chervonagura A, et al. Salivary characteristics of diabetic children. Braz Dent J 2003;14:26-31.

21. Sreedevi Shashikanth MC, Shambulingappa P. Comparison of serum glucose and salivary glucose in diabetic patients. J Indian Acad Oral Med Radiol 2008;20:9-13.

22. Jurysta C, Bulur N, Oguzhan B, Satman I, Yilmaz TM, Malaisse WJ, et al. Salivary glucose concentration and excretion in normal and diabetic subjects. J Biomed Biotechnol 2009;2009:430426.

23. Kortuem GM. Saliva glucose and blood glucose. Am J Clin Pathol 1944;14:70.

24. Shannon IL, Prigmore JR, Brooks RA. Glucose concentrations in parotid fluid and blood serum following intravenous glucose loading. Oral Surg Oral Med Oral Pathol 1960;13:1010-2.

25. Englander HR, Jeffay AI, Fuller JB, Chauncey HH. Glucose concentrations in blood plasma and parotid saliva of individuals with and without diabetes mellitus. J Dent Res 1963;42:1246.

26. Campbell MJ. Glucose in the saliva of the non-diabetic and the diabetic patient. Arch Oral Biol 1965;10:197-205.

27. Carlson AJ, Ryan JG. Glucose in saliva. Am J Physiol 1908;21:301-9.

28. Mahdavi SO, Hashemi S, Boostani NS, Zokaee H. A new method to evaluate fasting plasma glucose by salivary glucose measurement. Iran J Diabetes Obes 2012;4:127-32.

29. Panchbhai AS, Degwekar SS, Bhowte RR. Estimation of salivary glucose, salivary amylase, salivary total protein and salivary flow rate in diabetics in India. J Oral Sci 2010;52:359-68.

30. Priya SS, Bharani GO, Nagalingam M, Jayanthi M, Kanagavalli U. Potential of salivary protein as a biomarker in prognosis of diabetes mellitus. J Pharm Res 2011;4:2228-9.

31. Agrawal RP, Sharma N, Rathore MS, Gupta VB, Jain S, Agarwal V. Non-invasive method for glucose level estimation by saliva. J Diabetes Metab 2013;4:266.

32. Abikshyeet P, Ramesh V, Oza N. Glucose estimation in the salivary secretion of diabetes mellitus patients. Diabetes Metab Syndr 2012; 5:149-54.

33. Ivanovski K, Naumovski V, Kostadinova M, Pesevska S, Drijanska K, Filipce $\mathrm{V}$, et al. Xerostomia and salivary levels of glucose and urea in patients with diabetes. Prilozi 2012;33:219-29.

34. Bakianian Vaziri P, Vahedi M, Mortazavi H, Abdollahzadeh SH, Hajilooi M. Evaluation of salivary glucose, igA and flow rate in diabetic patients: A case-control study. J Dent (Tehran) 2010;7:13-8.

35. Vasconcelos AC, Soares MS, Almeida PC, Soares TC. Comparative study of the concentration of salivary and blood glucose in Type 2 diabetic patients. J Oral Sci 2010;52:293-8. 